\title{
Роль России в БРИКС в рамках взаимодействия в социальной сфере ${ }^{1}$
}

\author{
В.П. Кульпина, А.К. Морозкина, В.А. Павлюшина, Д.В. Шуваева
}

Кульпина Вера Петровна - студентка магистратуры Национального исследовательского университета «Высшая школа экономики»; Российская Федерация, 101000, Москва, ул. Мясницкая, 20; E-mail: vkulpina@gmail.com

Морозкина Александра Константиновна - аспирантка Национального исследовательского университета «Высшая школа экономики», эксперт Экономической экспертной группы; Российская Федерация, 109012, Москва, Ветошный пер., 5/4; E-mail: a.k.morozkina@gmail.com

Павлюшина Виктория Александровна - студентка магистратуры Национального исследовательского университета «Высшая школа экономики»; Российская Федерация, 101000, Москва, ул. Мясницкая, 20; E-mail: pa_victoria@mail.ru

Шуваева Дарья Валерьяновна - студентка магистратуры Национального исследовательского университета «Высшая школа экономики»; Российская Федерация, 101000, Москва, ул. Мясницкая, 20; E-mail: darias.s@yandex.ru

В 2015 г. Россия председательствует в БРИКС, и расширение сотрудничества в социальной сфере названо среди приоритетных тем. Данная статья посвящена обзору схожих проблем стран БРИКС в области социальной сферы и возможных направлений сотрудничества для их решения. Статья разделена на тематические разделы в области социальной сферы: социальная защита, здравоохранение, жсилищный вопрос и образование. В первом разделе затрагиваются проблемы безработицы и неравенства. Во втором разделе рассматриваются вопросы финансирования здравоохранения, охвата медицинскими услугами, борьбы с ВИЧ и неинфекционными заболеваниями. Третий раздел посвящен вопросам урбанизации и возможностям улучшения жилищных условий. Четвертый раздел посвящен вопросам охвата образованием, расходов на образованияе в странах пятерки, а также академической мобильности между странами БРИКС. Авторы приходят к выводу о том, что изучение опыта стран-партнеров по БРИКС может быть полезным для России, особенно в области прогрессивного налогообложения как борьбы с неравенством доходов, популяризации спорта и здорового образа жизни, применения механизма государственно-частного партнерства в сфере здравоохранения, а также кооперации в сфере академической мобильности с другими странами пятерки, унификации образовательных стандартов. Россия, в свою очередь, может в числе прочего предложить партнерам накопленный опыт в области охвата медицинскими услугами и образованием, федеральных программ поддержки социально уязвимых слоев населения.

Ключевые слова: БРИКС, устойчивое развитие, социальная сфера, здравоохранение, доступное жилье, образование, социальная защита

В последнее время страны БРИКС расширяют сотрудничество по целому ряду вопросов. Одно из приоритетных направлений взаимодействия стран Группы - социальная сфера. В настоящий момент в рамках БРИКС большое внимание уделяется проблемам, связанным именно с этой сферой: подписываются соглашения, разрабатываются программы по обмену опытом и форматы взаимопомощи по вопросам социальной за-

${ }^{1}$ Материал поступил в редакцию в марте 2015 г. 
щиты, здравоохранения, образования, обеспечения жильем. На последнем саммите, прошедшем в июле 2014 г. в Форталезе (Бразилия), главы государств не только подчеркнули важность и необходимость сотрудничества по социальным вопросам и письменно закрепили ряд инициатив, но и обсудили необходимость создания единой системы подсчета и представления статистических данных социальной сферы. В странах БРИКС проживает около 3 млрд человек, однако при этом достаточно большое количество вопросов социальной сферы остаются проблемными в разной степени. Обмен опытом, активное сотрудничество и совместное решение существующих вопросов социальной сферы необходимы для движения к устойчивому росту и развитию. При этом страны БРИКС способны выработать собственные подходы к решению проблем в данной области, которые позднее могут использоваться другими развивающимися странами. Данная статья посвящена сотрудничеству стран БРИКС по вопросам образования, здравоохранения, жилья и социальной защиты. Основной акцент при этом сделан на текущей и потенциальной роли России в различных проектах, а также возможных путях сотрудничества стран БРИКС в социальной сфере.

Россия, наряду с Бразилией и Китаем, входит в группу стран с высоким Индексом человеческого развития (ИЧР), занимая по данному показателю первое место среди стран БРИКС (табл. 1). Индия и ЮАР относятся к странам со среднеим уровнем человеческого развития. Рассматривая отдельные составляющие индекса, следует отметить лидерство России по текущему среднему количеству лет обучения и валовому национальному доходу (ВНД) на душу населения. Однако по ожидаемому количеству лет обучения лидирует уже Бразилия, а по продолжительности жизни Россия занимает и вовсе третье место в группе. Начиная с анализа ИЧР можно сделать вывод о важности опыта России прошлых лет в повышении уровня жизни населения и образования и необходимости для нее обращения к опыту остальных стран БРИКС в сфере здравоохранения.

Таблица 1. Индекс человеческого развития (ИЧР) стран БРИКС

\begin{tabular}{|c|l|c|c|c|c|c|}
\hline $\begin{array}{c}\text { Рейтинг } \\
\text { ИЧР, } \\
\mathbf{2 0 1 3} \text { г. }\end{array}$ & Страна & $\begin{array}{c}\text { Значение } \\
\text { индекса, } \\
\mathbf{2 0 1 3} \text { г. }\end{array}$ & $\begin{array}{c}\text { Ожидаемая про- } \\
\text { должительность } \\
\text { жизи при рожде- } \\
\text { нии, 2013 г. }\end{array}$ & $\begin{array}{c}\text { Среднее } \\
\text { число лет } \\
\text { обучения, } \\
\mathbf{2 0 1 3} \text { г. }\end{array}$ & $\begin{array}{c}\text { Ожидаемое } \\
\text { число лет обу- } \\
\text { чения, 2012 г. }\end{array}$ & $\begin{array}{c}\text { ВНД на душу, } \\
\mathbf{2 0 1 3} \text { г., в } \\
\text { ценах 2011 г, } \\
\text { долл. ППС }\end{array}$ \\
\hline 79 & Бразилия & 0,744 & 73,9 & 7,2 & 15,2 & 14,275 \\
\hline 57 & Россия & 0,778 & 68,0 & 11,7 & 14,0 & 22,617 \\
\hline 135 & Индия & 0,586 & 66,4 & 4,4 & 11,7 & 5,150 \\
\hline 91 & Китай & 0,719 & 75,3 & 7,5 & 12,9 & 11,477 \\
\hline 118 & ЮАР & 0,658 & 56,9 & 9,9 & 13,1 & 11,788 \\
\hline
\end{tabular}

Источник: UN [2014].

\section{Социальная защита}

Форталезская декларация БРИКС 2014 г. [BRICS Leaders, 2014] предполагает изучение новых областей сотрудничества, в том числе в сфере трудовых ресурсов и социального обеспечения. Встреча министров, отвечающих за социальное обеспечение (равно как 
и за образование и здравоохранение), включена в план действий декларации, принято решение о разработке совместной методологии расчета социальных показателей. Кроме того, недавно созданный Банк развития БРИКС предполагает реализацию проектов в сфере устойчивого развития - экономического развития при социальной и экологической устойчивости. В подготовленном по итогам Научного форума БРИКС «Долгосрочном видении развития БРИКС» [Observer Research Foundation, 2013] особое место уделяется понятиям устойчивого развития, социальной справедливости, качества жизни населения. Социальная справедливость - широкое понятие, связанное с обеспечением максимально равных возможностей для людей разного возраста, пола, расы, происхождения. В рамках БРИКС, в частности, большое внимание уделяется проблемам бедности и неравенства по доходам, гендерного неравенства, эффективности трудовых ресурсов. Страны приветствуют обмен опытом в реализации успешных социальных программ и схем различных выплат и пособий.

Таблица 2. Социально-экономические характеристики стран БРИКС, 2010-2013 гг.

\begin{tabular}{|c|c|c|c|c|c|c|}
\hline & $\begin{array}{c}\text { Рассматриваемый } \\
\text { период }\end{array}$ & Бразилия & Россия & Индия & Китай & ЮAP \\
\hline $\begin{array}{l}\text { Плотность населения, } \\
\text { чел./кв. м }\end{array}$ & 2011-2013 гг. & 23,6 & 8,4 & 382 & 141 & 42,3 \\
\hline $\begin{array}{l}\text { Ожидаемая } \\
\text { продолжительность } \\
\text { жизни при рождении, } \\
\text { лет }\end{array}$ & 2010-2013 гг. & 74,8 & 70,7 & 66,1 & 74,8 & 58,1 \\
\hline $\begin{array}{l}\text { Рождаемость, } \\
\text { на } 1000 \text { человек }\end{array}$ & 2011-2013 гг. & 14,8 & 13,2 & 21,6 & 12,1 & 21,6 \\
\hline $\begin{array}{l}\text { Экономически } \\
\text { активное население, } \\
\text { \% от общего } \\
\text { населения страны }\end{array}$ & 2012-2013 гг. & 65,9 & 52,7 & 53,1 & 56,6 & 35,4 \\
\hline $\begin{array}{l}\text { Население младше } \\
15 \text { лет, \% от общего } \\
\text { населения страны }\end{array}$ & 2011-2013 гг. & 24,1 & 16,1 & 29,1 & 16,5 & 30,0 \\
\hline $\begin{array}{l}\text { Безработица среди } \\
\text { городского населения, } \\
\%\end{array}$ & 2012-2013 гг. & 6,1 & 5,5 & 5,3 & 4,1 & 25,1 \\
\hline $\begin{array}{l}\text { Коэффициент Джини, } \\
\%\end{array}$ & 2010-2013 гг. & 50 & 42 & 37 & 47 & 65 \\
\hline
\end{tabular}

Источник: [BRICS, 2014].

Население стран БРИКС значительно отличается по своим социальноэкономическим характеристикам (табл. 2). Индия и ЮАР - это страны с относительно молодым населением, высокой рождаемостью; Россия и Китай сталкиваются с проблемой старения населения. В связи с этим, во-первых, большое внимание уделяется развитию возможностей для молодежи [Sinha, 2013], во-вторых, происходит реформирование пенсионной системы [Pozen, 2013]. В России со старением населения также борются путем стимулирования рождаемости - выплатой материнского капитала за второго и последующих детей. Бразилия находится в промежуточном положении и на 
данный момент имеет самую высокую в БРИКС долю экономически активного населения.

В России, в отличие от других стран БРИКС, не стоит вопрос борьбы с абсолютной бедностью. Поэтому программы, реализуемые, например, в Индии [Ministry of Rural Development, 2015], - работа за продукты питания, микрокредиты и скидки на питание определенным группам населения, или в ЮАР [Department of Cooperative Governance and Traditional Affairs, 2015] - создание рабочих мест в общественном секторе для отдаленных районов - неприменимы для России. В 2012 г. средняя заработная плата россиян более чем в 4,5 раза превышала прожиточный минимум. Доля людей с доходами ниже прожиточного минимума упала с 29\% в 2000 г. до 11\% в 2012 г. Однако вопреки официальной статистике значительная часть населения считает себя бедными (39\%) и даже крайне бедными (15\% в 2011 г.) [НИУ ВШЭ, 2011]. Это можно объяснить значительным ухудшением уровня жизни населения в 1990-е годы и возросшим неравенством по доходам (с 1990 по 1994 г. соотношение доходов 10\% самых богатых к 10\% самых бедных выросло с 4,5 до 15 раз).

В последние десятилетия степень неравенства по доходам возросла во всех странах БРИКС. Наихудшая из группы ситуация наблюдается в ЮАР, наилучшая - в Индии (коэффициент Джини составляет 65\% и 37\% соответственно, табл. 1). Риски, создаваемые подобным расслоением общества, признаются на государственном уровне и минимизируются через механизмы налогообложения и социальной защиты. Россия может изучить опыт введения прогрессивного налогообложения, которое используют остальные страны БРИКС.

В настоящий момент во всех странах - членах БРИКС законодательно закреплены как механизмы социальной защиты для трудоспособного населения и их семей (пособия по временной нетрудоспособности, отпуск по уходу за ребенком и болезни), так и для нуждающегося и нетрудоспособного населения (пособия для инвалидов, сирот). Первые предполагают совместное финансирование государством, компаниями и работниками, вторые происходят в основном только за счет государства.

Для борьбы с безработицей и неравенством страны БРИКС потенциально могут задействовать трудовую миграцию, причем не только на уровне обмена квалифицированными специалистами. Структура занятости по отраслям (рис. 1) и различия в плотности населения (табл. 1) теоретически позволяют странам выгодно задействовать многостороннюю трудовую миграцию, особенно при росте безработицы в определенных секторах. Тем не менее сейчас внутри БРИКС не только трудовая миграция, но и туризм имеют определенные препятствия для развития. Безвизовый режим существует только между Бразилией и Россией, Бразилией и ЮАР.

На данный момент ни одна из стран не ратифицировала «Международную конвенцию по защите прав всех трудящихся-мигрантов и их семей». В целом лидером по ратификации конвенций/протоколов ООН по правам человека [UN Human Rights, 2015] является Бразилия (15 из 18), следом идет ЮАР (13), затем Россия (11). Китай и Индия ратифицировали по восемь конвенций.

Представители российской власти не раз заявляли, что готовы пожертвовать экономическим ростом для поддержки социально уязвимых слоев населения. В 2004 г. был создан Стабилизационный фонд, разделившийся затем на Резервный фонд и Фонд национального благосостояния, являющийся эффективным финансовым механизмом реализации социальных программ [Международная ассоциация социального обеспечения, 2012]. С точки зрения затрагиваемой темы такая последовательность в политике может быть примером для других стран БРИКС, в особенности для Китая, проходяще- 


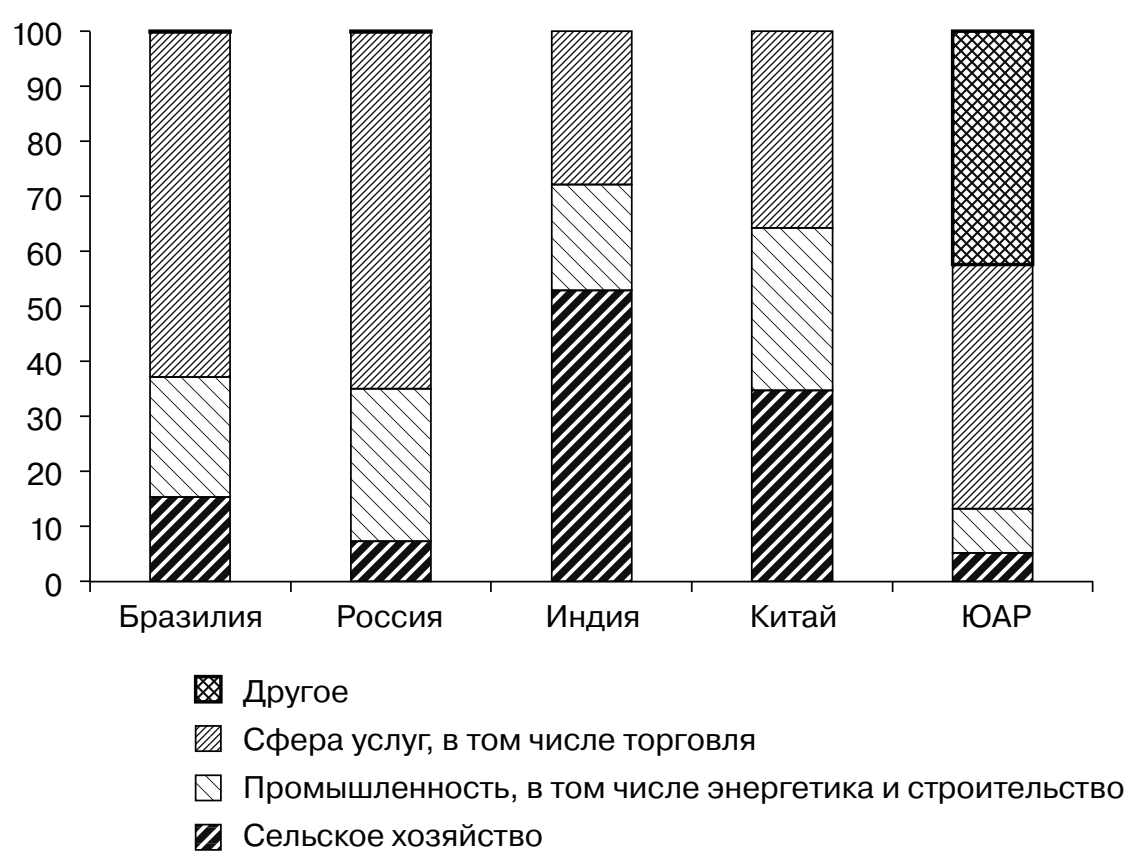

Рuc. 1. Структура занятости в странах БРИКС по отраслям, 2012 г.

Источник: [BRICS, 2014].

го через процесс трансформации своей модели развития [Grinin et al., 2014]. C 2001 по 2012 г. расходы на социальные выплаты (включая пенсии, стипендии, пособия по безработице, материнский капитал) в ВВП возросли с 9 до 12\%. В 2012 г. деятельность государственных агентств занятости обеспечила работой 2,9 млн граждан, 64\% от общего числа безработных. Кроме того, повышение уровня жизни населения реализуется через ряд государственных программ. Например, с 2013 г. реализуется программа «Социальная поддержка граждан» ${ }^{2}$. Среди целевых индикаторов обозначено снижение доли населения, имеющего доход ниже прожиточного минимума, до 9\%, обеспечение $100 \%$-го охвата социальной помощью для всех обратившихся, увеличение коэффициента рождаемости до 1,753 (детей в расчете на одну женщину) к 2017 г. На четыре подпрограммы («Развитие мер социальной поддержки отдельных категорий граждан», «Модернизация и развитие социального обслуживания населения», «Совершенствование социальной поддержки семьи и детей», «Повышение эффективности государственной поддержки социально ориентированных некоммерческих организаций») выделено 9,5 трлн руб.

Несмотря на разнородные задачи в сфере социального обеспечения, странам БРИКС будет полезен обмен опытом в области политики по повышению адресности существуюших и вновь вводимых программ. Известным примером является бразильская программа "Bolsa Família”, предполагающая целевые денежные переводы бедным гражданам на развитие человеческого капитала. Также в числе общих проблем в сфере социального обеспечения следует отметить защиту самозанятых работников и работников неформального сектора.

${ }^{2}$ Государственная программа «Социальная поддержка граждан». Министерство труда и социального развития Российской Федерации. Режим доступа: http://www.rosmintrud.ru/ministry/ programms/3/2/Sotcialynaya_podderzhka_grazhdan_vizualizatciya_itog.pdf (дата обращения: 22.10.2015). 
Наконец, у стран БРИКС есть возможность вместе выступить в рамках разработки новых «Целей устойчивого развития» ООН, продолжающих «Цели тысячелетия», по которым они в целом показали неплохие результаты по относящимся к социальной защите аспектам - борьбе с бедностью и дискриминацией.

\section{Здравоохранение}

В вопросах здравоохранения также есть поле для кооперации в странах БРИКС и обмена опытом. Основными вопросами в сфере здравоохранения, в которых страны БРИКС могли бы сотрудничать, являются расширение охвата медицинскими услугами, борьба с ВИЧ и неинфекционными заболеваниями. Вопросы здравоохранения впервые были отмечены как перспективные для диалога в БРИКС в рамках декларации, принятой по итогам саммита в Санье в 2011 г. [BRICS Leaders, 2011]. После этого состоялась первая встреча министров здравоохранения, и в первой декларации были названы следующие общие для стран БРИКС вопросы: всеобщий доступ к медицинским услугам и лекарствам, расходы на здравоохранение, инфекционные заболевания (ВИЧ, туберкулез), а также неинфекционные заболевания [BRICS Health Ministers, 2011].

На второй встрече министры здравоохранения отметили среди прочих такую тему, как контроль за табакокурением и «исследование факторов, влияющих на его распространение» [BRICS Health Ministers, 2013a]. Также было принято обязательство по совместному «развитию инфраструктуры для снижения распространения туберкулеза путем изобретения новых лекарств и вакцин, диагностики и стимулирования сотрудничества ученых в этой области» [Ibid.]. Отдельно была отмечена необходимость «предотвращения распространения ВИЧ путем обмена информацией и опытом, развития новых услуг диагностики, а также быстрого повышения доступности лечения» [BRICS Health Ministers, 2013a]. В декларации также содержался пункт о «контроле над распространением инфекционных и неинфекционных заболеваний путем обмена информацией, развития инструментов оценки риска, методов его снижения, оценки влияния государственной политики всех уровней на здоровье населения» [Ibid.].

На третьей встрече министры здравоохранения обозначили ключевые темы для сотрудничества стран БРИКС [BRICS Health Ministers, 2013b], а также по каждому из пяти направлений были созданы рабочие группы:

- стратегические технологии в области борьбы с инфекционными болезнями

(под руководством Бразилии);

- медицинские технологии (под руководством России);

- укрепление системы санитарно-эпидемиологического надзора (под руководством Индии);

- изобретение и разработка лекарств (под руководством Китая);

- борьба с неинфекционными заболеваниями, профилактика, пропаганда здоровья и всеобъемлющий охват медицинскими услугами (под руководством ЮАР).

В то же время осязаемые результаты пока не достигнуты и информации о результатах деятельности созданных рабочих групп также нет - возможно, они будут представлены на следующей встрече министров здравоохранения. Однако это не означает, что сотрудничество между странами БРИКС в области здравоохранения неэффективно. Необходимо продолжать искать точки соприкосновения и направления, где опыт одних стран мог бы быть полезен другим или где общие усилия пяти стран могут дать больший результат, нежели действия поодиночке - от развития общих медицинских технологий до продвижения нового формата сотрудничества в рамках международных организаций. 
Например, Индия могла бы поделиться опытом использования механизмов ГЧП, поскольку ее расходы на здравоохранение относительно развитых стран невелики (табл. 2), и развитие данного направления может потребовать дополнительных затрат. Это, в частности, может быть полезно для России, поскольку в нашей стране масштабы использования механизма ГЧП в здравоохранении пока достаточно малы, по большей части в силу отсутствия законодательства на федеральном уровне.

Таблица 2. Расходы на здравоохранение в странах БРИКС, 2012 г.

\begin{tabular}{|l|c|c|c|c|c|}
\hline Страна & $\begin{array}{c}\text { Доля государствен- } \\
\text { ных расходов на } \\
\text { здравооранение, } \\
\text { \% в общих расходах }\end{array}$ & $\begin{array}{c}\text { Расходы } \\
\text { на здраво- } \\
\text { охранение, на } \\
\text { душу населения } \\
\text { (долл. по ППС) }\end{array}$ & $\begin{array}{c}\text { Государственные } \\
\text { расходы на здраво- } \\
\text { охранение, на душу } \\
\text { населения } \\
\text { (долл. по ППС) }\end{array}$ & $\begin{array}{c}\text { Доля } \\
\text { расходов } \\
\text { на здраво- } \\
\text { охранение } \\
\text { в ВВП, \% }\end{array}$ & $\begin{array}{c}\text { Доля част- } \\
\text { ных расходов } \\
\text { на здраво- } \\
\text { охранение } \\
\text { в ВВП, \% }\end{array}$ \\
\hline Бразилия & 46 & 1109 & 515 & 9,3 & 5,0 \\
\hline Россия & 61 & 1474 & 899 & 6,3 & 2,4 \\
\hline Индия & 33 & 157 & 52 & 4,0 & 2,7 \\
\hline Китай & 56 & 480 & 269 & 5,4 & 2,4 \\
\hline ЮАР & 48 & 982 & 470 & 8,8 & 4,6 \\
\hline
\end{tabular}

Источник: База данных Всемирной организации здравоохранения [WHO, 2015].

Общей проблемой стран БРИКС является охват медицинскими услугами и лекарственными средствами (табл. 3). Охват медицинскими лекарствами из развивающихся стран в России самый высокий, поэтому она может делиться опытом в успешных областях с другими партнерами по БРИКС. В то же время сохраняется проблема охвата медицинскими услугами сельской местности, и данному вопросу продолжает уделяться большое внимание. В частности, в 2011 г. был принят закон «Об основах охраны здоровья граждан Российской Федерации», в котором четко указана всеобщность доступа к медицинским услугам. Основой предоставления бесплатных медицинских услуг на всеобщей основе является система обязательного медицинского страхования, которая регулируется законом 2010 г. «Об обязательном медицинском страховании».

В Бразилии охват медицинскими услугами существенно расширился с 1988 г., когда была принята единая медико-санитарная система, однако доступ все еще не является всеобщим. Так, система «Здоровья семьи», которая лежит в основе единой медико-санитарной системы, покрывает около 95 млн человек, т.е. чуть менее половины населения страны [Humphreys, Jurberg, 2010], а не все население, как в России. Доступность лекарственных средств, особенно в государственных учреждениях, остается очень низкой (в соответствии с исследованием ВО3, выбранного набора лекарственных средств не оказалось в государственных аптеках).

В Индии система характеризуется большой долей частного сектора и использованием платных услуг, а также низким качеством и слабой степенью надзора за рынком частных медицинских услуг [Prinja et al., 2012]. В настоящее время создается система всеобщего доступа к медицинским услугам, и именно сейчас, во время перехода к новой системе, опыт России был бы полезен. 
Таблица 3. Доступность лекарственных средств в странах БРИКС, 2013 г.

\begin{tabular}{|l|c|c|c|c|}
\hline Страна & $\begin{array}{c}\text { Средняя } \\
\text { доступность } \\
\text { некоторых } \\
\text { непатентованных } \\
\text { лекарственных } \\
\text { средств*, частные } \\
\text { аптеки }\end{array}$ & $\begin{array}{c}\text { Средняя доступность } \\
\text { некоторых } \\
\text { непатентованных } \\
\text { лекарственных } \\
\text { средств*, } \\
\text { государственные } \\
\text { аптеки }\end{array}$ & $\begin{array}{c}\text { Индекс стоимости } \\
\text { некоторых } \\
\text { лекарственных } \\
\text { средств**, частные } \\
\text { аптеки }\end{array}$ & $\begin{array}{c}\text { Индекс стоимости } \\
\text { некоторых } \\
\text { лекарственных } \\
\text { средств**, } \\
\text { государственные } \\
\text { аптеки }\end{array}$ \\
\hline Бразилия & 77 & 0 & 11,3 & Н. д. \\
\hline Россия & 100 & 100 & 4,1 & 2,7 \\
\hline Индия & 77 & 22 & 1,9 & Н. д. \\
\hline Китай & 13 & 16 & 1,4 & 1,6 \\
\hline ЮАР & 71 & 52 & 6,5 & Н. д. \\
\hline
\end{tabular}

* Процент аптек из выборки, в которых есть в наличии выбранный набор лекарственных средств.

** Отношение медианной стоимости избранного набора лекарственных средств к ориентировочной цене, установленной организацией «Наука управления здравоохранением».

Источник: База данных Всемирной организации здравоохранения [WHO, 2015].

В Китае в настоящее время продолжается процесс расширения охвата населения (особенно сельского) медицинскими услугами. Согласно официальным данным, охват среди сельского населения составляет уже 95\% [Liang, Langenbrunner, 2013]. Учитывая большое внимание, которое уделяется этому вопросу в Китае, и схожесть проблем, в том числе обеспечение качественного медицинского обслуживания в рамках государственной системы при всеобщем охвате данной услугой, Китай и Россия могли бы сотрудничать в этом направлении и делиться опытом.

В ЮАР в настоящее время внедряется программа Национального медицинского страхования. Планируется внедрять данную систему еще около десяти лет, но уже есть успехи - в рамках системы антивирусной терапии был обеспечен доступ к лечению около 2 млн человек [Harmer, 2014].

Вторая проблема, обсуждаемая в рамках БРИКС, решение которой очень актуально для России, - это борьба с ВИЧ. Тенденция роста распространенности ВИЧ в России в последнее время вызывает обеспокоенность - за последние семь лет число зараженных удвоилось, с каждым годом число ежегодных новых случаев инфицирования ВИЧ растет. В частности, это можно отнести на счет улучшения системы выявления данного заболевания, однако также к основным причинам относят рост заболеваемости наркоманией. Другие страны БРИКС тоже обеспокоены проблемой ВИЧ (табл. 4), поэтому кооперация в данной сфере могла бы быть полезна всем странам пятерки. В частности, сотрудничество может состоять в обмене опытом по борьбе с ВИЧ, создании совместных вакцин.

Проблема неинфекционных заболеваний особенно актуальна для России, поэтому опыт других стран БРИКС может быть очень полезен. Одним из способов снижения заболеваемости является здоровый образ жизни, в том числе регулярные занятия спортом. Китай считается особенно успешным примером популяризации здорового образа жизни в целом и регулярных занятий спортом в частности. Основной частью плана действий «Спорт для всех», запущенного в 1996 г., было строительство площадок для 
занятий спортом и оснащение их соответствующим образом. Аналогичный приоритет содержался в плане «Дорога к здоровью», одобренном в 1997 г. [WHO, 2005]. В 2014 г. был подготовлен новый пакет мер, согласно которому к 2025 г. планируется увеличение площади спортивных сооружений до 2 квадратных метров на человека.

Таблица 4. Показатели в области ВИЧ в странах БРИКС, 2013 г. (если не указано иное)

\begin{tabular}{|l|c|c|c|}
\hline \multicolumn{1}{|c|}{ Страна } & $\begin{array}{c}\text { Распространенность ВИЧ } \\
\text { среди населения в возрасте } \\
\text { от 15 до 49 лет }\end{array}$ & Число смертей от ВИЧ & $\begin{array}{c}\text { Кол-во человек, живущих } \\
\text { с ВИЧ (данные за 2009 г.) }\end{array}$ \\
\hline Бразилия & 0,5 & 16000 & 490000 \\
\hline Россия & 1,1 & 20511 & 980000 \\
\hline Индия & 0,3 & 130000 & 2088642 \\
\hline Китай & 0,1 & 26000 & 780000 \\
\hline ЮАР & 17,9 & 200000 & 6400000 \\
\hline
\end{tabular}

* Отношение числа людей в возрасте от 15 до 49 лет с ВИЧ к общему числу людей в этом возрасте.

Источник: База данных Всемирной организации здравоохранения [WHO, 2015].

Таблица 5. Смертность и факторы риска здоровью в странах БРИКС

\begin{tabular}{|c|c|c|c|c|c|c|}
\hline Страна & $\begin{array}{c}\text { Смертей на } \\
100 \text { тыс. чел. } \\
\text { населения, } \\
2013 \text { г. }\end{array}$ & $\begin{array}{c}\text { Всего, } \\
\text { смертей } \\
\text { от НИЗ, } \\
\text { тыс. } \\
\text { человек, } \\
2013 \text { г. }\end{array}$ & \begin{tabular}{|c|} 
Недостат. физ. \\
активность*, \\
2008 г.
\end{tabular} & $\begin{array}{c}\text { Потребл. } \\
\text { алкоголя***, } \\
2010 \text { г. }\end{array}$ & $\begin{array}{c}\text { Ожирение } \\
\text { (индекс } \\
\text { массы тела } \\
\text { больше } \\
30)^{* * *} \text {, } \\
\mathbf{2 0 0 8} \text { г. }\end{array}$ & \begin{tabular}{|c|} 
Табако- \\
курение \\
2011 г.**
\end{tabular} \\
\hline Бразилия & 514 & 978 & 49,4 & 7,38 & 19,5 & 22 \\
\hline Россия & 790 & 1802 & 20,8 & 11,12 & 24,9 & 59 \\
\hline Индия & 682 & 5869 & 15,6 & 2,46 & 1,9 & 25 \\
\hline Китай & 576 & 8577 & 31 & 5,75 & 5,6 & 47 \\
\hline ЮAP & 711 & 264 & 52,4 & 7,77 & 33,5 & 28 \\
\hline
\end{tabular}

НИЗ - неинфекционные заболевания.

* Доля населения, которая уделяет в неделю менее 150 мин активности с умеренной интенсивностью или менее 75 мин активности с высокой интенсивностью.

** Потребление совершеннолетними (старше 15 лет) алкоголя за год в расчете на одного человека (в литрах).

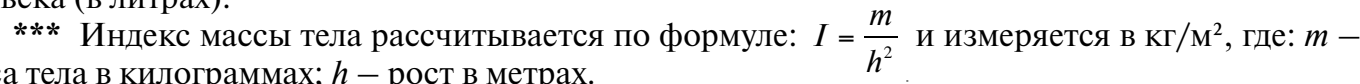
масса тела в килограммах; $h$ - рост в метрах.

**** Доля курящих совершеннолетних (старше 15 лет) в численности населения старше 15 лет.

Источник: База данных Всемирной организации здравоохранения [WHO, 2015].

В борьбе с туберкулезом одним из средств является повышение акцизов на табачную продукцию. Так, в России стоимость пачки сигарет одна из самых низких - 
1,7 долл. США, тогда как в Китае, Бразилии и ЮАР цена составляет 2,1, 2,7 и 3,3 долл. соответственно. В развитых странах цена еще выше - 6,3 долл. в США, 6,9 долл. в Германии.

Также для России было бы перспективным сотрудничество со странами БРИКС в сфере создания лекарственных средств, в частности с индийской фармацевтической промышленностью. Так, 80\% препаратов, использовавшихся в терапевтических мероприятиях, профинансированных донорами ВОЗ в развивающихся странах, были произведены в Индии. Около 60-80\% всех закупаемых ООН вакцин также произведены в Индии [Harmer, 2014]. В то же время страны БРИКС активно выступают за передачу технологий, а не только предоставление лекарств и врачебной помощи [Kickbusch, 2014]. Продвижение нового формата сотрудничества также могло бы стать приоритетом стран БРИКС в области здравоохранения.

\section{Жилищные условия}

Экономический подъем и быстрая урбанизация ставят сложные задачи по обеспечению населения жильем и достойными условиями существования. Особое значение эта проблема принимает в развивающихся странах, где темпы урбанизации в разы превышают темпы экономического развития или жилищное строительство не поспевает за экономическим бумом. В результате могут возникнуть проблемы неформальных поселений, неравенства, бедности, недостойных условий жизни, равного доступа к базовым услугам. Для стран БРИКС проблема жилья также является весьма актуальной, хотя и имеет разные проявления в зависимости от страны.

Страны БРИКС обсуждают вопросы жилья и условий жизни в рамках Форума по вопросам урбанизации и Форума сотрудничества породненных городов и муниципальных образований государств-участников. Эти две площадки призваны содействовать кооперации и обмену опытом в области урбанизации, развития городов, борьбы с бедностью и неравенством. На последнем Форуме, прошедшем в 2013 г. в Дурбане, страны-участники отметили возрастающую значимость процессов урбанизации и выделили приоритеты совместной работы на последующих Форумах (следующий будет проведен в Бразилии в 2015 г.): взаимосвязь и совместное развитие города и деревни, развитие моногородов и «затухающих» районов, устойчивое развитие городов [BRICS Leaders, 2013].

Городское развитие является одним из приоритетных направлений социальной политики стран БРИКС не только на межстрановом уровне самой площадки, но и во внутренней политике. Несмотря на различия во внутриэкономической, демографической и социальной ситуациях, управление процессом урбанизации и развитие сельских местностей является актуальной темой для всех стран БРИКС, хотя и проявляется в разных аспектах. В четырех из пяти стран БРИКС (за исключением Индии) доля городского населения превышает долю сельского. Индия - наименее урбанизированная страна, всего $32 \%$ населения проживает в городах, в то время как в Бразилии - $85 \%$. В то же время Бразилия и Россия имеют наименьшие темпы урбанизации, тогда как в Китае, Индии и ЮАР процессы урбанизации идут весьма активно. В случае с показателями доступности улучшенных санитарных условий показатели коррелируют с процентом городского населения: улучшенные санитарные условия в Бразилии имеет $81 \%$ жителей - вдвое больше, чем в Индии (36\%). В то же время, несмотря на различающиеся модальности процессов, страны сталкиваются со схожими задачами в сфере обеспечения жильем. 
Таблица 6. Базовые показатели урбанизации в странах БРИКС, 2014 г.

\begin{tabular}{|l|c|c|c|c|c|}
\hline Страна & $\begin{array}{c}\text { Городское на- } \\
\text { селение, \% от } \\
\text { общей числен- } \\
\text { ности населе- } \\
\text { ния }\end{array}$ & $\begin{array}{c}\text { Темпы урба- } \\
\text { низации, \% } \\
\text { ежегодно }\end{array}$ & $\begin{array}{c}\text { Население, } \\
\text { проживающее } \\
\text { в крупнейших } \\
\text { городах, \% } \\
\text { от городского } \\
\text { населения }\end{array}$ & $\begin{array}{c}\text { Население, про- } \\
\text { живающее } \\
\text { в агломерациях } \\
\text { с населением более } \\
\text { 1 млн человек, \% } \\
\text { от общей числен- } \\
\text { ности населения }\end{array}$ & $\begin{array}{c}\text { Улучшенные } \\
\text { санитарные усло- } \\
\text { вия* \% населения } \\
\text { с доступом }\end{array}$ \\
\hline Бразилия & 85 & 1,2 & 12 & 40 & 81 \\
\hline Россия & 74 & 0,3 & 12 & 21 & 71 \\
\hline Индия & 32 & 2,4 & 6 & 14 & 36 \\
\hline Китай & 53 & 2,9 & 3 & 23 & 65 \\
\hline ЮАР & 64 & 2,2 & 27 & 38 & 74 \\
\hline
\end{tabular}

* Улучшенные санитарные условия предполагают соблюдение гигиенических норм: смыв (подключение к канализационной системе, септики, выгребные ямы), надворная уборная с вентилируемым выгребом (VIP), биотуалет.

Источник: База данных Всемирного банка [WB, 2015].

Важно отметить, что страны БРИКС имеют и общие проблемы. В рамках сотрудничества в области устойчивого развития городов и решения социальных проблем странам БРИКС логично обратить внимание на общую для всех проблему - неблагоприятные жилищные условия. По оценкам МакКинзи, Россия, Бразилия, Индия и Китай входят в десятку стран с наибольшей концентрацией жителей с неблагоприятными жилищными условиями, причем Китай и Индия занимают первые два места, Бразилия - четвертое [Woetzel et al., 2014].

Естественно, проблема неблагоприятных жилищных условий имеет весьма специфический «окрас» в разных странах, для Бразилии речь идет о фавелах, для Индии и Китая - о трущобах, для Южной Африки - о трущобах и неформальных поселениях, для России - о ветхом жилье, старых зданиях.

Во всех странах реализуются программы по улучшению жилищных условий граждан, однако для России нет специализированной комплексной политики в области неблагоприятных жилищных условий: ремонт и переселение из ветхого жилья осуществляются в каждом случае по решению межведомственной комиссии, организованной на основании заявления граждан или надзорного органа (Положение «О признании помещения жилым помещением, жилого помещения непригодным для проживания и многоквартирного дома аварийным и подлежащим сносу или реконструкции»). В то же время в остальных странах БРИКС существуют конкретные цели и универсальные программы (или подпрограммы) по устранению неблагоприятных жилищных условий. Конечно, это в значительной степени связано с большей остротой проблемы в остальных странах БРИКС, поскольку трущобы имеют там намного более неформальную и опасную специфику. Тем не менее для России анализ опыта стран - партнеров по БРИКС в области целевого комплексного управления улучшением неблагоприятных жилищных условий мог бы стать толчком к развитию данной области.

Россия, несмотря на существующие жилищные проблемы в настоящем, имеет успешный опыт массового строительства доступного жилья в прошлом (во времена Н. Хрущева), поэтому может поделиться своим опытом в историческом контексте и активно участвовать в сотрудничестве по реализации существующих программ. 
Таблица 7. Неблагоприятные жилищные условия в странах БРИКС, данные за 2009 г.

\begin{tabular}{|l|c|c|c|c|c|}
\hline & Бразилия & Россия & Индия & Китай & ЮАР \\
\hline $\begin{array}{l}\text { Доля городского населения, имеющего } \\
\text { неблагоприятные жилищные условия, } \%\end{array}$ & 27 & 12 & 29 & 27 & $23^{*}$ \\
\hline $\begin{array}{l}\text { Количество людей, имеющих } \\
\text { неблагоприятные жилищные условия, } \\
\text { млн человек }\end{array}$ & 11 & Н. д. & 28 & 62 & Н. д. \\
\hline
\end{tabular}

* Доля городского населения, проживающего в трущобах.

Источник: [UN, 2015; Woetzel et al., 2014].

Нарастающие темпы урбанизации позволяют говорить о большом потенциале развития рынка доступного жилья. Особый упор на доступное, дешевое жилье во всех странах БРИКС позволяет сделать именно эту нишу рынка основой для будущего взаимодействия и обмена опытом. Россия, Бразилия, Индия и Китай входят в пятерку стран (плюс Нигерия), которые к 2025 г. станут наиболее привлекательными рынками строительства доступного жилья [Woetzel et al., 2014].

В Бразилии дефицит жилья оценивается в 5,8 млн единиц [Becker, 2014]. Согласно государственной программе «Мой дом, моя жизнь», к 2014 г. планируется строительство 3,4 млн домов [Becker, 2014], государство предоставляет субсидии и налоговые льготы с целью стимулировать строительство и обновление зданий для последующей продажи домохозяйствам с доходом до 5 тыс. реалов. К середине 2012 г. более 800 тыс. семей въехали в новые дома, было заключено более 1,7 млн контрактов на строительство [Bahia, 2013].

В России реализуется программа «Обеспечение доступным и комфортным жильем и коммунальными услугами граждан Российской Федерации», в рамках которой к 2017 г. предполагается построить 25 млн квадратных метров жилой площади. Подпрограмма «Жилье для российской семьи» будет реализована за счет выпуска облигаций с залоговым обеспечением, что снизит цену для конечных покупателей. Также предполагается финансовая поддержка малообеспеченных граждан через предоставление займов, материнского капитала и иных форм финансовой поддержки. Подпрограмма нацелена на малообеспеченных граждан, граждан, проживающих в неблагоприятных условиях, многодетные семьи.

В Индии наблюдается значительный дефицит жилой площади, который с ростом населения будет только усиливаться. Согласно оценкам, необходимо построить 19 млн дешевых домов [The BRICS Post, 2014]. В 2007 г. была сформулирована Национальная политика городского жилья и жилищных условий (National Urban Housing and Habitat Policy), которая поставила цель «доступное жилье для всех» и была сфокусирована на развитии партнерства частного и государственного секторов в области обеспечения жильем и помощи беднейшим слоям населения. Национальная миссия по обновлению городского жилья имени Джавахарлала Неру, запушенная в 2005 г. и продленная до 2014 г., является флагманской программой Индии в области городского развития. Программа распространяется на 65 городов, где нехватка жилых площадей вызывает появление неформальных поселений, рост жилья с неблагоприятными условиями и повышение цен на покупку и аренду. 
Таблица 8. Сравнение программ стран БРИКС по обеспечению населения доступным жильем

\begin{tabular}{|c|c|c|c|c|}
\hline Страна & $\begin{array}{c}\text { Название } \\
\text { программы }\end{array}$ & Цель & Стоимость & Основной инструмент \\
\hline Бразилия & $\begin{array}{l}\text { Программа «Мой } \\
\text { дом - моя жизнь» } \\
\text { (Mihna Casa Minha } \\
\text { Vida) }\end{array}$ & 3,4 млн ед. & 18 млрд долл. США & $\begin{array}{l}\text { Субсидии и налоговые } \\
\text { льготы }\end{array}$ \\
\hline Россия & $\begin{array}{l}\text { Обеспечение } \\
\text { доступным и } \\
\text { комфортным } \\
\text { жильем и } \\
\text { коммунальными } \\
\text { услугами граждан } \\
\text { РФ }\end{array}$ & $\begin{array}{l}\text { До } 100 \text { млн м² } \\
\text { жилой площади } \\
\text { к } 2020 \text { г. }\end{array}$ & $\begin{array}{l}577934420,6 \\
\text { тыс. руб. }\end{array}$ & $\begin{array}{l}\text { Облигации с залоговым } \\
\text { обеспечением, } \\
\text { финансовая поддержка, } \\
\text { займы, трансферты }\end{array}$ \\
\hline Индия & $\begin{array}{l}\text { Национальная } \\
\text { миссия по } \\
\text { обновлению } \\
\text { городского жилья } \\
\text { им. Джавахарлала } \\
\text { Неру }\end{array}$ & $\begin{array}{l}\text { Общая нехватка } \\
\text { достойного } \\
\text { жилья - } \\
26,53 \text { млн ед. } \\
\text { Нет данных }\end{array}$ & $\begin{array}{l}\text { Бюджет составил } \\
60 \text { тыс. крор } \\
\text { (крор }=10 \text { млн } \\
\text { рупий) }\end{array}$ & $\begin{array}{l}\text { Проектное } \\
\text { финансирование, } \\
\text { льготные кредиты }\end{array}$ \\
\hline Китай & $\begin{array}{l}\text { Программа } \\
\text { экономичного и } \\
\text { удобного жилья } \\
\text { (Economical } \\
\text { and Comfortable } \\
\text { Housing), } \\
\text { Программа } \\
\text { дешевой apeнды } \\
\text { жилья (Cheap } \\
\text { Rental Housing) }\end{array}$ & 7 млн домов & $\begin{array}{l}\text { Общие } \\
\text { государственные } \\
\text { расходы на } \\
\text { доступное жилье } \\
\text { оцениваются } \\
\text { в } 900 \text { млрд юаней }\end{array}$ & $\begin{array}{l}\text { Специализированный } \\
\text { жилищный фонд } \\
\text { (The Housing Provident } \\
\text { Fund) }\end{array}$ \\
\hline ЮAP & $\begin{array}{l}\text { Комплексная } \\
\text { политика } \\
\text { департамента } \\
\text { жилищного } \\
\text { строительства }\end{array}$ & $\begin{array}{l}\text { Общая нехватка } \\
\text { достойного } \\
\text { жилья - } \\
2,1 \text { млн ед. }\end{array}$ & $\begin{array}{l}\text { В 2013-2014 гг. } \\
\text { бюджет Департа- } \\
\text { мента жилищного } \\
\text { строительства } \\
\text { составил } \\
28 \text { млрд ранд }\end{array}$ & $\begin{array}{l}\text { Субсидии, льготные } \\
\text { кредиты }\end{array}$ \\
\hline
\end{tabular}

Источник: [Правительство РФ, 2014; Acro Iris Brazil, 2012; Burra, 2014; Deng et al., 2009; Human Settlements, 2013].

В Китае активно развиваются программы доступного жилья для населения. В 2015 г. планируется начать строительство 7 млн дешевых домов для жителей с низкими доходами [The BRICS Post, 2014]. Согласно планам, в 2015 г. доступное жилье должно покрывать до 20\% жилых массивов [The BRICS Post, 2013]. Реализуются программы экономичного и удобного жилья (Economical and Comfortable Housing), дешевой аренды жилья (Cheap Rental Housing). Особенно интересен опыт Китая по созданию Специального фонда (The Housing Provident Fund), взносы в который вносят и работодатель, и нанимаемый, последний при этом получает право получить низкие ставки по ипотечному кредиту [Deng et al., 2009].

Согласно Концепции жилищного развития до 2030 г. (Human Settlement Vision), в ЮАР наблюдается нехватка 2,1 млн жилых помещений - почти 12,5 млн человек. Департамент жилищного строительства напрямую субсидирует наименее обеспеченные 
домохозяйства [Human Settlements, 2012]. Существует также Национальная корпорация по финансированию жилья, предоставляющая займы, облигации и ипотечные кредиты, причем корпорация финансирует не только покупку домов, но и проекты социального строительства. С 1994/95 по 2013 г. Департамент жилищного строительства смог обеспечить строительство более 2,8 млн домов, при этом, согласно переписи 2011 г., бараков и незаконных зданий насчитывалось более 1,9 млн. Общая стоимость решения жилищной проблемы к 2020 г. (ликвидация неформальных поселений и обеспечение жильем) оценивается в 800 млрд ранд [Wilkinson, 2014].

\section{Образование}

Страны БРИКС могут также сотрудничать в сфере образования. Среди основных направлений взаимодействия по вопросам образования можно выделить следующие: укрепление систем образования для обеспечения качества и справедливости, совершенствование высшего образования, совершенствование развития навыков в интересах экономического роста, выгодного для всех, оказание поддержки образования в других развивающихся странах [UNESCO, 2014].

Первая встреча министров образования стран БРИКС состоялась в штабквартире ЮНЕСКО в Париже осенью 2013 г., целью встречи стало обсуждение вопросов сотрудничества в сфере образования как внутри БРИКС, так и взаимодействия Группы с ЮНЕСКО, вторая - в Москве в марте 2015 г. Встречи стали воплощением одной из Деклараций стран БРИКС, принятой на саммите в Санье (Китай, 2011 г.), а именно - создание группы ЮНЕСКО - БРИКС для сотрудничества в сферах компетенции ЮНЕСКО, т.е. в том числе в сфере образования. Основным результатом встреч стало принятие решения о взаимодействии стран Группы по вопросам образования, а также практическое осуществление инициатив с помощью различных инструментов ЮНЕСКО. ЮНЕСКО при этом взяла на себя обязательство содействовать странам БРИКС путем изучения тенденций в образовании, различных политических мер и выступать в роли площадки для обмена знаниями и опытом.

Идеи, высказанные министрами образования на первой встрече, нашли свое продолжение в Декларации, принятой по результатам шестого Саммита БРИКС, прошедшего в июле 2014 г. в Форталезе (Бразилия). На саммите главы государств признали образование одним из стратегических направлений развития стран Группы для достижения устойчивого развития. При этом на том же саммите были закреплены обязательства по укреплению сотрудничества в данной области. Это свидетельствует о том, что взаимодействие в данной сфере вышло на новый уровень.

Вопрос образования в странах БРИКС актуален по ряду причин. В настоящее время университеты стран БРИКС больше взаимодействуют с университетами стран внутри своего региона, нежели внутри Группы. Осознавая важность подготовки кадров, а также развития связей разных университетов стран Группы, в Коммюнике Саммита БРИКС в Форталезе также было отмечено высокое значение образования для устойчивого развития и стабильного экономического роста стран Группы, а также необходимость кооперации и создания единой сети университетов стран БРИКС. Инициатива создания единой сети университетов БРИКС предполагает введение различных программ получения двойных дипломов в полной мере уже с 2016 г., что, безусловно, увеличит поток студентов. На саммите в Форталезе также было решено, что в каждой из стран Группы должны признаваться дипломы о высшем образовании университе- 
тов стран БРИКС. Важно отметить, что там же было принято решение о создании Сетевого Университета БРИКС - высшего заведения нового типа для студентов как из стран БРИКС, так и других стран мира. По задумке Университет будет способствовать подготовке ученых и формированию собственной сети исследователей, все занятия будут проходить в онлайн-режиме. Согласно плану, первые студенты начнут обучение с 2017 г. Отметим также, что до этого, 6 июля 2013 г., в Шанхае было подписано соглашение о создании Лиги Университетов стран БРИКС, которая будет представлять собой площадку для экспертного и академического взаимодействия по вопросам высшего образования. Эти же идеи были поддержаны на Глобальном университетском Саммите, прошедшем в Москве в 2015 г.

Последние реформы в сфере образования, проведенные в странах БРИКС, привели к значительному увеличению охвата населения по уровням образования. Особенно сильно изменилась ситуация в Индии и Бразилии по сравнению с 1999 г. Из табл. 9 видно, что Российская Федерация по охвату населения является лидером, а значит, может поделиться опытом в ходе сотрудничества стран БРИКС по вопросам образования. Важно, чтобы программа повышения образованности населения проходила одновременно с решением проблем бедности, описанных выше, так как такие низкие показатели для высшего и среднего уровня образования в Индии связаны именно с тем, что образование по-прежнему недоступно для беднейших слоев населения, которые в основном проживают в сельской местности. Несмотря на отсутствие точных данных для Бразилии, показатели охвата населения для нее хоть и чуть выше индийских, но схожи по тренду.

Таблица 9. Охват образования по уровням в странах БРИКС, 2013 г.

\begin{tabular}{|l|c|c|c|c|c|}
\hline \multirow{2}{*}{ Страна } & \multicolumn{5}{|c|}{ Уровни образования } \\
\cline { 2 - 6 } & Дошкольный & Школьный & $\begin{array}{c}\text { Нижний } \\
\text { средний }\end{array}$ & $\begin{array}{c}\text { Высший } \\
\text { средний }\end{array}$ & Высший \\
\hline Бразилия & Н. д. & Н. д. & Н. д. & Н. д. & Н. д. \\
\hline Китай & 62,3 & 104,2 & 100,1 & 84 & 27 \\
\hline Индия & 58 & 113 & 86 & 55 & 25 \\
\hline $\begin{array}{l}\text { Российская } \\
\text { Федерация }\end{array}$ & 91 & 101 & 94 & 98 & 76 \\
\hline Южная Африка & 77 & 102 & 111 & 96 & 19 \\
\hline
\end{tabular}

Источник: [UNESCO, 2014].

Данные табл. 10, 11 позволяют сделать вывод о том, что Индия значительно отстает от остальных стран БРИКС по уровню грамотности населения, и при этом лишь малая часть государственных расходов приходится на образование. Таким образом, тезис о том, что Индии необходимо обратить внимание на опыт стран БРИКС (в частности Южной Африки) в вопросах охвата населения и структуры государственных расходов, актуален, так как для улучшения ситуации в сфере образования необходимы значительные инвестиции. Консультантом по данному вопросу может выступить российская сторона, так как показатели России находятся на самом высоком уровне. 
Таблица 10. Уровень грамотности в странах БРИКС, \% от возрастной группы, 2013 г.

\begin{tabular}{|l|c|c|}
\hline \multicolumn{1}{|c|}{ Страна } & Взрослые (от 15 лет и старше) & Школьный возраст (15-24 года) \\
\hline Бразилия & 91 & 99 \\
\hline Китай & 95 & 100 \\
\hline Индия & 63 & 81 \\
\hline $\begin{array}{l}\text { Российская } \\
\text { Федерация }\end{array}$ & 100 & 100 \\
\hline Южная Африка & 94 & 99 \\
\hline
\end{tabular}

Источник: [UNESCO, 2014].

Таблица 11. Государственные расходы на образование в странах БРИКС

\begin{tabular}{|c|c|c|c|c|c|c|c|c|}
\hline \multirow[t]{3}{*}{ Страна } & \multicolumn{4}{|c|}{$\begin{array}{l}\text { Общие государственные } \\
\text { расходы на образование }\end{array}$} & \multicolumn{4}{|c|}{$\begin{array}{c}\text { Общие государственные расходы на каждом } \\
\text { уровне образования как \% от текущих } \\
\text { государственных расходов на образование }\end{array}$} \\
\hline & \multicolumn{2}{|c|}{ \% от ВВП } & \multicolumn{2}{|c|}{$\begin{array}{l}\text { \% от государ- } \\
\text { ственных } \\
\text { расходов }\end{array}$} & Дошкольный & Школьный & Средний & Высший \\
\hline & 19992. & 20122. & 19992. & 20122. & \multicolumn{4}{|c|}{ За 2012 г. или самые новые из доступных данные } \\
\hline Бразилия & 3,9 & 5,8 & 9,5 & 14,6 & 7,6 & 31,3 & 44,7 & 16,4 \\
\hline Китай & 1,9 & 3,7 & 11,4 & 16,3 & 5 & 33 & 23,3 & - \\
\hline Индия & 4,3 & 3,4 & 16,3 & 11,3 & 1,1 & 23,4 & 37,3 & 37,6 \\
\hline $\begin{array}{l}\text { Российская } \\
\text { Федерация }\end{array}$ & 2,9 & 4,1 & 9,0 & 12,0 & 15,0 & Н. д. & Н. д. & 23,1 \\
\hline $\begin{array}{l}\text { Южная } \\
\text { Африка }\end{array}$ & 6,0 & 6,6 & Н. д. & 20,6 & 1,4 & 39,9 & 30,3 & 11,9 \\
\hline
\end{tabular}

Источник: [UNESCO, 2014].

Немаловажно отметить, что в настоящее время академическая мобильность между странами находится на очень низком уровне. Из табл. 12 видно, что наиболее высока доля китайских студентов в университетах других стран БРИКС. Это обусловлено, с одной стороны, тем, что в странах БРИКС в принципе мало развита система обучения студентов в зарубежных вузах, существует лишь небольшое количество государственных программ, которые способствуют увеличению потока студентов на обучение за границей. При этом сотрудничество стран БРИКС должно быть сфокусировано на том, чтобы создать возможность для студентов из стран БРИКС обучаться в университетах других стран Группы. Несмотря на все положительные инициативы относительно создания сети университетов, особое внимание стоит уделить созданию программ (в первую очередь - магистерских) на английском языке, что значительно увеличит поток иностранных студентов.

Если говорить о Российской Федерации, то необходимо принять больше государственных программ финансирования и помощи российским студентам для обучения за рубежом, в частности - в университетах стран БРИКС с условием возвращения на 
работу в Россию. При этом в рамках кооперации стран БРИКС можно обратить внимание на опыт Китая, который наиболее прогрессивен в данном вопросе.

Таблица 12. Международная академическая мобильность в странах БРИКС, конец 2014 г., человек

\begin{tabular}{|l|c|c|c|c|c|}
\hline \multirow{2}{*}{ Обучаются в: } & \multicolumn{5}{|c|}{ Студенты из: } \\
\cline { 2 - 6 } & Бразилии & Китая & Индии & $\begin{array}{c}\text { Российской } \\
\text { Федерации }\end{array}$ & $\begin{array}{c}\text { Южной } \\
\text { Африки }\end{array}$ \\
\hline Бразилии & Н. д. & 316 & 16 & 36 & 145 \\
\hline Китае & Н. д. & Н. д. & Н. д. & Н. д. & Н. д. \\
\hline Индии & 4 & 682 & Н. д. & 18 & 109 \\
\hline $\begin{array}{l}\text { Российской } \\
\text { Федерации }\end{array}$ & 200 & 9842 & 3351 & Н. д. & 3 \\
\hline Южной Африке & 52 & 465 & 411 & 62 & Н. д. \\
\hline
\end{tabular}

Источник: [UNESCO, 2014].

Таким образом, можно сделать вывод о том, что в последние два года взаимодействие между странами БРИКС по вопросам образования усилилось, однако в настоящий момент остаются вопросы, решение которых в рамках БРИКС пока не предусмотрено. Если говорить о высшем образовании, то стоит отметить Университет БРИКС как успешную форму взаимодействия. Тем не менее можно привести следующие рекомендации по расширению сотрудничества в сфере высшего образования:

- Для существенной интенсификации взаимодействия необходимо создание единой информационной платформы, с помощью которой студенты смогут ознакомиться с существующими для них возможностями. При этом вся информация должна быть представлена на доступном им языке (например, английском). В настоящее время единой базы программ не существует, а те сведения, которые можно найти в информационных источниках стран Группы, не всегда доступны на английском и/или других языках.

- Наряду с системой признания дипломов и квалификаций должна быть разработана система взаимозачета кредитов для студентов (за образец может быть взята уже существующая и функционирующая в мире), так как эти два изменения являются ключевыми для увеличения интенсивности кросс-граничного высшего образования и мобильности студентов.

- Должна быть создана кросс-граничная сеть «университет - работодатель», которая обеспечит понимание у абитуриентов потребностей работодателей не только из своих стран, но также и других стран Группы. В настоящее время этому аспекты проблемы уделяется мало внимания, поэтому те студенты, которые окончили вуз по существующим программам обмена, не могут найти работу по специальности.

Если говорить о школьном образовании, то по различным показателям в Группе отстают ЮАР и Индия, третье место занимает Бразилия. Для решения проблем школьного образования необходимо привлечь успешный опыт российских программ, а также создать аналог Университета БРИКС для школьного образования.

Представленный анализ четырех основных сфер социально-экономической политики показывает, что страны БРИКС в настоящее время сотрудничают и планируют наращивать сотрудничество по различным вопросам в этих сферах. Несомненно, все 
эти проблемы важны и их необходимо решать. Однако, на наш взгляд, наряду с вышеперечисленными вопросами нужно обратить внимание на те возможности и блага, которые получают жители каждой из пяти стран по результатам политического сближения стран БРИКС. По нашему мнению, можно обратить внимание на визовый режим для жителей каждой из стран. Несмотря на то, что для путешествий в некоторые страны жителям стран БРИКС виза не нужна (например, отсутствие визового режима между Бразилией и Россией), а между некоторыми странами визовый режим упрощен (Индия - Россия), для некоторых путешествующих, например из России в Китай или ЮАР, из Китая в ЮАР или Россию, получение виз затруднено. Именно поэтому, по нашему мнению, сотрудничество стран БРИКС должно осуществляться не только в социально важных областях, но и на уровне жителей стран - с целью интенсификации проникновения культур.

\section{Заключение}

Страны БРИКС сотрудничают по различным проблемным вопросам социальной сферы и совместно борются с такими проблемами, как бедность, неграмотность, социальное неравенство, охват образования и здравоохранения, лечение ВИЧ, доступность жилья для населения. Если говорить о Российской Федерации, то необходимо отметить, что наша страна может успешно делиться опытом по таким вопросам, как уровень грамотности, охват образования и здравоохранения. При этом было бы полезно внимательно изучить опыт других стран БРИКС в вопросах финансирования здравоохранения, академической мобильности, адресных программ социальной защиты. Страны БРИКС пока находятся на этапе формирования повестки в данной области, и многие инициативы закреплены только на бумаге. Несмотря на отсутствие в настоящий момент ощутимых результатов и значительные различия, Группе необходимо продолжать углублять кооперацию по вопросам социальной сферы.

Россия может получить ощутимые выгоды от сотрудничества БРИКС в социальной сфере. Во-первых, изучить лучшие законодательные практики стран Группы по вопросам обеспечения доступным жильем, сглаживания неравенства в доходах. Во-вторых, получить доступ к передовым медицинским технологиям и способам пропаганды здорового образа жизни, наладить обмен специалистами в данной сфере. В-третьих, обрести надежных партнеров для повышения качества высшего образования - важнейшей составляющей развития человеческого капитала. С другой стороны, исторический опыт России и сохраняющийся на данный момент высокий приоритет социальной сферы в развитии страны с соответствующими программами будет полезен остальным странам - членам БРИКС.

\section{Литература}

Международная ассоциация социального обеспечения (2012) Социальное обеспечение в странах БРИКС: сравнительное исследование расширения охвата в Бразилии, Российской Федерации, Индии, Китае и Южной Африке. Краткий обзор. Режим доступа: https://goo.gl/Ao8KSb (дата обращения: 22.10.2015).

НИУ ВШЭ (2011) Обследование «Родители и дети, мужчины и женщины в семье и обществе». Режим доступа: http://www.socpol.ru/gender/RIDMIZ.shtml (дата обращения 28.01.2015).

Правительство РФ (2014) Программа «Обеспечение доступным и комфортным жильем и коммунальными услугами граждан РФ». Режим доступа: http://government.ru/docs/11914/ (дата обращения: 22.10.2015). 
Acro Iris Brazil (2012) Brochure Arco Iris Development. Режим доступа: https://www.google.ru/url?sa=t $\& \mathrm{rct}=\mathrm{j} \& \mathrm{q}=\& \mathrm{esrc}=\mathrm{s} \&$ source $=$ web\& $\mathrm{cd}=2 \& \mathrm{ved}=0 \mathrm{CCQQFjABahUKEwiav9-ehuXIAhVLjiwKHWlHB} 8 \mathrm{U} \&$ url=http\%3A\%2F\%2Fwww.topa.co.uk\%2Fpropertydocs\%2Fdoc_257.pdf\&usg=AFQjCNHQn7R3doqUQ UGllq3J103g51qLw\&sig2=FfM6r9yYJK7UBKeAzlMEIQ\&bvm=bv.106130839,d.bGg (дата обращения: 26.01.2015).

Bahia S. (2013) Minha Casa, Minha Vida: Federal Housing Policy in Brazil. Режим доступа: http://favelissues. com/2013/06/09/minha-casa-minha-vida-federal-housing-policy-in-brazil/ (дата обращения: 25.01.2015).

Becker S. (2014) Minha Casa, Nossa Cidade: Brazil's Social Housing Policy \& The Failures of the PrivatePublic System. Режим доступа: http://www.archdaily.com/504114/minha-casa-nossa-cidade-brazil-s-socialhousing-policy-and-the-failures-of-the-private-public-system/ (дата обращения 28.01.2014).

BRICS (2014) Joint Statistical Publication. Режим доступа: http://brics.ibge.gov.br/downloads/BRICS Joint_Statistical_Publication_2014.pdf (дата обращения: 25.01.2015).

BRICS Health Ministers (2011) Beijing Declaration. Режим доступа: http://www.mid.ru/brics.nsf/0/66A1B2 E6460EB69DC32578DC0038982E/\$file/img-718104543-0001.pdf (дата обращения: 25.01.2015).

BRICS Health Ministers (2013a) Delhi Communique. Режим доступа: http://www.brics.utoronto.ca/ docs/130111-health.html (дата обращения: 25.01.2015).

BRICS Health Ministers (2013b) Cape Town Communique. Режим доступа: http://www.brics.utoronto.ca/ docs/131107-health.html (дата обращения: 25.01.2015).

BRICS Leaders (2011) Sanya Declaration. Режим доступа: http://eng.news.kremlin.ru/ref_notes/45 (дата обращения: 25.01.2015).

BRICS Leaders (2013) 2nd BRICS Urbanisation Forum, The Durban Declaration. Режим доступа: http:// www.brics5.co.za/assets/The-2nd-BRICS-Urbanisation-Forum-The-Durban-Declaration-1-November28th-2013-Durban-KwaZulu-Natal-South-Africa.pdf (дата обращения 27.01.2015).

BRICS Leaders (2014) Fortaleza Declaration. Режим доступа: http://news.kremlin.ru/media/events/ files/41d4f1dd6741763252a8.pdf (дата обращения: 25.01.2015).

Burra S. (2014) The Jawaharlal Nehru National Urban Renewal Mission (JNNURM): Lessons learnt. 5 November. Effective States and Inclusive Development Research Centre. Режим доступа: http://www. effective-states.org/the-jawaharlal-nehru-national-urban-renewal-mission-jnnurm-lessons-learnt/ (дата обращения 29.01.2015).

Deng L., Qingyun S., Wang L. (2009) Housing Policy and Finance in China: A Literature Review. Режим доступа: http://www.chinaplanning.org/Publications/Lan\%20Deng\%20-\%20Housing\%20Policy\%20and\%20 Finance\%20In\%20China.pdf (дата обращения 26.01.2015).

Grinin L.E., Tsirel S.V., Korotayev A. (2014) Will the Explosive Growth of China Continue?// Technological Forecasting and Social Change. Vol. 81. No. 12.

Harmer A. (2014) The BRICS Countries: A New Force in Global Health? Interview. Bulletin of the World Health Organization. Vol. 92. No. 6. Режим доступа: www.who.int/bulletin/volumes/92/6/en/ (дата обращения: 25.01.2015).

Human Settlements (2012) Pocket Guide to South Africa 2012/13. Режим доступа: http://www.gcis.gov.za/ sites/www.gcis.gov.za/files/docs/resourcecentre/pocketguide/2012/12\%20Human\%20Settlements.pdf (дата обращения: 29.01.2015).

Human Settlements (2013) Human Settlements Review: Economics and Finance. Pretoria: Department of Human Settlements Republic of South Africa. Режим доступа: http://www.dhs.gov.za/sites/default/files/ documents/publications/Human\%20Settlements\%20Review\%20Edition\%201\%202013.pdf (дата обращения: 26.01.2015).

Humphreys G., Jurberg C. (2010) Brazil's March Towards Universal Coverage. Bulletin of the World Health Organization. Vol. 88. No. 9. Р. 641-716. Режим доступа: http://www.who.int/bulletin/volumes/88/9/10020910/en/\# (дата обращения: 25.01.2015).

Kickbusch I. (2014) BRICS' Contributions to the Global Health Agenda 2013. Bulletin of the World Health Organization. Vol. 92. №. 6. Режим доступа: www.who.int/bulletin/volumes/92/6/en/ (дата обращения: 25.01.2015). 
Liang L., Langenbrunner J.C. (2013) The Long March to Universal Coverage: Lessons from China. Studies Series. No. 9. Washington D.C.: World Bank. Режим доступа: http://documents.worldbank.org/curated/ en/2013/01/17207313/long-march-universal-coverage-lessons-china (дата обращения: 25.01.2015).

Ministry of Rural Development (2015) National Social Assistance Programme. Режим доступа: http://nsap. nic.in/nsap/NSAP-\%20About\%20us.pdf (дата обращения: 28.01.2015).

Observer Research Foundation (2013) A Long-term Vision for BRICS. Режим доступа: http://orfonline. org/cms/export/orfonline/modules/report/attachments/bricsvision_1376295709857.pdf (дата обращения: 10.02.2015).

Pozen R.C. (2013) Tackling the Chinese Pension System. Режим доступа: http://www.paulsoninstitute.org/ media/105497/china_pensions_pozen_english_final.pdf (дата обращения: 25.01.2015).

Prinja S., Kaur M., Kumar R. (2012) Universal Health Insurance in India: Ensuring Equity, Efficiency and Quality // Indian Journal Community Medicine. No. 37 (3). P. 142-149. Режим доступа: http://www.ncbi. nlm.nih.gov/pubmed/23112438 (дата обращения: 26.01.2015).

Sinha P. (2013) Combating Youth Unemployment in India. Режим доступа: http://library.fes.de/pdf-files/ iez/09728.pdf (дата обращения: 25.01.2015).

The BRICS Post (2013) Xi Pushes for Affordable Housing in China. Режим доступа: http://thebricspost. com/xi-pushes-for-affordable-housing-in-china/ (дата обращения: 25.01.2015).

The BRICS Post (2014) China to Build 7 Million Low-cost Homes in 2015. Режим доступа: http://thebricspost. com/china-to-build-7-million-low-cost-homes-in-2015/ (дата обращения: 25.01.2015).

UN (2014) Human development report 2014. Sustaining Human Progress: Reducing Vulnerabili-ties and Building Resilience. Режим доступа: http://hdr.undp.org/sites/default/files/hdr14-report-en-1.pdf (дата обращения: 22.10.2015).

UN (2015) Millennium Development Goals Indicators. Режим доступа: http://mdgs.un.org/unsd/mdg/ Data.aspx (дата обращения: 22.10.2015).

UN Human Rights (2015) Ratification of 18 International Human Rights Treaties. Режим доступа: http:// indicators.ohchr.org/ (дата обращения: 28.01.2015).

UNESCO (2014) BRICS: Building Education for the Future. Recommendations for Cooperation. Режим доступа: http://unesdoc.unesco.org/images/0022/002296/229692e.pdf (дата обращения: 22.10.2015).

WB (2015) Urban Development Indicators. Режим доступа: http://data.worldbank.org/indicator (дата обращения: 22.10.2015).

WHO (2005) Review of Best Practice in Interventions to Promote Physical Activity in Developing Countries. Background Document Prepared for the WHO Workshop on Physical Activity and Public Health. Beijing, 24-27 October. Режим доступа: http://www.who.int/dietphysicalactivity/bestpracticePA2008.pdf (дата обращения: 22.10.2015).

WHO (2015) Global Health Observatory Data Repository. Режим доступа: http://apps.who.int/gho/ data/?theme=home (дата обращения: 22.10.2015).

Wilkinson K. (2014) Factsheet: The Housing Situation in South Africa. Africa Check. Режим доступа: https:// africacheck.org/factsheets/factsheet-the-housing-situation-in-south-africa/ (дата обращения: 25.01.2015).

Woetzel J., Ram S., Mischke J., Garemo N., Sankhe S. (2014) A Blueprint for Addressing the Global Affordable Housing Challenge. Report of McKinsey Global Institute. October. Режим доступа: http://www. mckinsey.com/insights/urbanization/tackling_the_worlds_affordable_housing_challenge (дата обращения: 25.01.2015). 


\title{
Russia - BRICS Cooperation on Social Issues
}

\author{
V. Kulpina, A. Morozkina, V. Pavlyushina, D. Shuvaeva
}

Vera Kulpina - Master student at National Research University Higher School of Economics; 20 Myasnitskaya, 101000 Moscow, Russian Federation; E-mail: vkulpina@gmail.com

Alexandra Morozkina - Ph.D student at National Research University Higher School of Economics, Expert at Economic Expert Group; 20 Myasnitskaya, 101000 Moscow, Russian Federation; E-mail: a.k.morozkina@gmail. com

Victoria Pavlyushina - Master student at National Research University Higher School of Economics; 20 Myasnitskaya, 101000 Moscow, Russian Federation; E-mail: pa_victoria@mail.ru

Daria Shuvaeva - Master student at National Research University Higher School of Economics; 20 Myasnitskaya, 101000 Moscow, Russian Federation; E-mail: darias.s@yandex.ru

\begin{abstract}
This year is a year of Russian presidency in BRICS, and fostering of cooperation in social sphere is declared among priority themes. This article deals with the common issues of BRICS countries in social sphere and possible ways of cooperation to address them. Article is divided into four thematic areas: social protection, healthcare, housing and education. First part highlights unemployment and inequality issues. Second part deals with the questions of healthcare financing, coverage of medical services, HIV/AIDS and non-communicable diseases response. Third item is dedicated to urbanization and quality of housing issues. Fourth part underscores questions of coverage of education, expenses on it and academic mobility between five countries.

Article concludes that the analysis of the partner-countries experiences may be quite beneficial for Russia, especially in the sphere of progressive taxation as a mechanism to fight inequality, promotion of healthy lifestyle, public private partnership in healthcare, cooperation in academic mobility, education standards unification. Russia in its turn can share experience in healthcare and education coverage, national programmes of social protection of vulnerable social groups.
\end{abstract}

Key words: BRICS, sustainable development, social sphere, healthcare, housing, education, social security

\section{References}

Acro Iris Brazil (2012) Brochure Arco Iris Development. Available at: https://www.google.ru/url?sa=t\&rct=j\&q $=\&$ esrc $=$ s\&source $=$ web\&cd=2\&ved=0CCQQFjABahUKEwiav9-ehuXIAhVLjiwKHWlHB8U\&url=http\%3 A\%2F\%2Fwww.topa.co.uk\%2Fpropertydocs\%2Fdoc_257.pdf\&usg=AFQjCNHQn7R3doqUQUGllq3JI1O3 g51qLw\&sig2=FfM6r9yYJK7UBKeAzlMEIQ\&bvm=bv.106130839,d.bGg (accessed 26 January 2015).

Bahia S. (2013) Minha Casa, Minha Vida: Federal Housing Policy in Brazil. Available at: http://favelissues. com/2013/06/09/minha-casa-minha-vida-federal-housing-policy-in-brazil/ (accessed 26 January 2015).

Becker S. (2014) Minha Casa, Nossa Cidade: Brazil's Social Housing Policy \& The Failures of the Private-Public System. Available at: http://www.archdaily.com/504114/minha-casa-nossa-cidade-brazil-s-social-housingpolicy-and-the-failures-of-the-private-public-system/ (accessed 26 January 2015).

BRICS (2014) Joint Statistical Publication. Available at: http://brics.ibge.gov.br/downloads/BRICS_Joint_ Statistical_Publication_2014.pdf (accessed 26 January 2015).

BRICS Health Ministers (2011) Beijing Declaration. Available at: http://www.mid.ru/brics.nsf/0/66A1B2E646 0EB69DC32578DC0038982E/\$file/img-718104543-0001.pdf (accessed 26 January 2015).

BRICS Health Ministers (2013a) Delhi Communique. Available at: http://www.brics.utoronto.ca/docs/130111health.html (accessed 25 January 2015).

BRICS Health Ministers (2013b) Cape Town Communique. Available at: http://www.brics.utoronto.ca/ docs/131107-health.html (accessed 25 January 2015). 
BRICS Leaders (2011) Sanya Declaration. Available at: http://eng.news.kremlin.ru/ref_notes/45 (accessed 25 January 2015).

BRICS Leaders (2013) 2nd BRICS Urbanisation Forum, The Durban Declaration. Available at: http://www. brics5.co.za/assets/The-2nd-BRICS-Urbanisation-Forum-The-Durban-Declaration-1-November-28th2013-Durban-KwaZulu-Natal-South-Africa.pdf (accessed 27 January 2015).

BRICS Leaders (2014) Fortaleza Declaration. Available at: http://news.kremlin.ru/media/events/files/41d4f 1dd6741763252a8.pdf (accessed 25 January 2015).

Burra S. (2014) The Jawaharlal Nehru National Urban Renewal Mission (JNNURM): Lessons Learnt. 5 November. Effective States and Inclusive Development Research Centre. Available at: http://www.effective-states.org/ the-jawaharlal-nehru-national-urban-renewal-mission-jnnurm-lessons-learnt/ (accessed 29 January 2015).

Deng L., Qingyun S., Wang L. (2009) Housing Policy and Finance in China: A Literature Review. Available at: http://www.chinaplanning.org/Publications/Lan\%20Deng\%20-\%20Housing\%20Policy\%20and\%20Finance\%20In\%20China.pdf (accessed 26 January 2015).

Grinin L. E., Tsirel S. V., Korotayev A. (2014) Will the Explosive Growth of China Continue? Technological Forecasting and Social Change, vol. 81, no 12.

Harmer A. (2014) The BRICS Countries: A New Force in Global Health? Interview. Bulletin of the World Health Organization, vol. 92, no 6. Available at: www.who.int/bulletin/volumes/92/6/en/ (accessed 25 January 2015).

Higher School of Economics (2011) Obsledovanie «Roditeli i deti, muzhchiny $i$ zhenshhiny v sem'e i obshhestve» [The Survey «Parents and the Children, Men and Women in Family and Society»]. Available at: http://www. socpol.ru/gender/RIDMIZ.shtml (accessed 28 January 2015).

Human Settlements (2012) Pocket Guide to South Africa 2012/13. Available at: http://www.gcis.gov.za/sites/www. gcis.gov.za/files/docs/resourcecentre/pocketguide/2012/12\%20Human\%20Settlements.pdf (accessed 29 January 2015).

Human Settlements (2013) Human Settlements Review: Economics and Finance. Available at: http://www.dhs. gov.za/sites/default/files/documents/publications/Human\%20Settlements\%20Review\%20Edition\%201\%20 2013.pdf (accessed 26 January 2015).

Humphreys G., Jurberg C. (2010) Brazil's March Towards Universal Coverage. Bulletin of the World Health Organization, vol. 88, no 9, pp. 641-716. Available at: http://www.who.int/bulletin/volumes/88/9/10-020910/ en/\# (accessed 25 January 2015).

International Social Security Association (2012) Social'noe obespechenie v stranah BRIKS: sravnitel'noe issledovanie rasshirenija ohvata v Brazilii, Rossijskoj Federacii, Indii, Kitae i Juzhnoj Afrike. Kratkij obzor. [Social Security in the BRICS Countries: A Comparative Study of Expanding Coverage in Brazil, Russia, India, China and South Africa. Brief overview]. Available at: https://goo.gl/Ao8KSb (accessed 22 October 2015).

Kickbusch I. (2014) BRICS' Contributions to the Global Health Agenda 2013. Bulletin of the World Health Organization, vol. 92, no 6. Available at: www.who.int/bulletin/volumes/92/6/en/ (accessed 25 January 2015).

Liang L., Langenbrunner J.C. (2013) The Long March to Universal Coverage: Lessons from China. Studies Series, no 9. Washington D.C.: World Bank. Available at: http://documents.worldbank.org/curated/ en/2013/01/17207313/long-march-universal-coverage-lessons-china (accessed 25 January 2015).

Ministry of Rural Development (2015) National Social Assistance Programme. Available at: http://nsap.nic.in/ nsap/NSAP-\%20About\%20us.pdf (accessed 28 January 2015).

Observer Research Foundation (2013) A Long-term Vision for BRICS. Available at: http://orfonline.org/cms/ export/orfonline/modules/report/attachments/bricsvision_1376295709857.pdf (accessed 10 February 2015).

Pozen R.C. (2013) Tackling the Chinese Pension System. Available at: http://www.paulsoninstitute.org/ media/105497/china_pensions_pozen_english_final.pdf (accessed 25 January 2015).

Prinja S., Kaur M. and Kumar R. (2012) Universal Health Insurance in India: Ensuring Equity, Efficiency and Quality. Indian Journal Community Medicine, no 37(3), p. 142-149. Available at: http://www.ncbi.nlm.nih. gov/pubmed/23112438 (accessed 26 January 2015). 
Sinha P. (2013) Combating Youth Unemployment in India. Available at: http://library.fes.de/pdf-files/iez/09728. pdf (accessed 25 January 2015).

The BRICS Post (2013) Xi Pushes for Affordable Housing in China. Available at: http://thebricspost.com/xipushes-for-affordable-housing-in-china/ (accessed 25 January 2015).

The BRICS Post (2014) China to Build 7 Million Low-cost Homes in 2015. Available at: http://thebricspost. com/china-to-build-7-million-low-cost-homes-in-2015/ (accessed 25 January 2015).

The Russian Government (2014) Programma "Obespechenie dostupnym i komfortnym zhil'em i kommunal'nymi uslugami grazhdan RF" [The State Program "Providing Affordable and Comfortable Housing and Communal Services of Citizens of the Russian Federation]. Available at: http://government.ru/docs/11914/ (accessed 22 October 2015).

UN (2014) Human development report 2014. Sustaining Human Progress: Reducing Vulnerabilities and Building Resilience. Available at: http://hdr.undp.org/sites/default/files/hdr14-report-en-1.pdf (accessed 22 October 2015).

UN (2015) Millennium Development Goals Indicators. Available at: http://mdgs.un.org/unsd/mdg/Data.aspx (accessed 22 October 2015).

UN Human Rights (2015) Ratification of 18 International Human Rights Treaties. Available at: http://indicators. ohchr.org/ (accessed 25 January 2015).

UNESCO (2014) BRICS: Building Education for the Future. Recommendations for Cooperation. Available at: http://unesdoc.unesco.org/images/0022/002296/229692e.pdf (accessed 22 October 2015).

WB (2015) Urban Development Indicators. Available at: http://data.worldbank.org/indicator (accessed 22 October 2015).

WHO (2005) Review of Best Practice in Interventions to Promote Physical Activity in Developing Countries. Background Document Prepared for the WHO Workshop on Physical Activity and Public Health. Beijing, 24-27 October. Available at: http://www.who.int/dietphysicalactivity/bestpracticePA2008.pdf (accessed 22 October 2015).

WHO (2015) Global Health Observatory Data Repository. Available at: http://apps.who.int/gho/ data/?theme $=$ home (accessed 22 October 2015).

Wilkinson K. (2014) Factsheet: The Housing Situation in South Africa. Africa Check. Available at: https:// africacheck.org/factsheets/factsheet-the-housing-situation-in-south-africa/ (accessed 25 January 2015).

Woetzel J., Ram S., Mischke J., Garemo N., Sankhe S. (2014) A Blueprint for Addressing the Global Affordable Housing Challenge. Report of McKinsey Global Institute. October. Available at: http://www.mckinsey.com/ insights/urbanization/tackling_the_worlds_affordable_housing_challenge (accessed 25 January 2015). 